\title{
Numerical Investigation of Anode Thickness on the Performance and Heat/Mass Transport Phenomenon for an Anode-Supported SOFC Button Cell
}

\author{
Shiang-Wuu Perng and Chang-Ren Chen \\ Department of Mechanical Engineering, Kun Shan University, Tainan 710, Taiwan \\ Correspondence should be addressed to Shiang-Wuu Perng; peter@mail.ksu.edu.tw
}

Received 10 September 2014; Accepted 7 December 2014

Academic Editor: Mohamed Bououdina

Copyright (C) 2015 S.-W. Perng and C.-R. Chen. This is an open access article distributed under the Creative Commons Attribution License, which permits unrestricted use, distribution, and reproduction in any medium, provided the original work is properly cited.

\begin{abstract}
This study analyzes how anode thickness and working temperature affect heat/mass transport characteristics and cell performance of the anode-supported SOFC button cell by the finite-volume SIMPLE-C method coupled with preconditioned conjugate gradient methods. The numerical results of this work are compared with the experimental data and good agreement is observed. The simulation is carried out for various anode thicknesses $(0.1,0.5$, and $1.0 \mathrm{~mm})$ and working temperatures $(873,1073$, and $1273 \mathrm{~K})$. The results showed that the cell performance reduces about $5.05 \%$ as the anode thickness is increased from $0.1 \mathrm{~mm}$ to $1.0 \mathrm{~mm}$; however, the influence of anode thickness on the heat/mass transport phenomenon is slight because the geometric size of anode thickness is tiny for the whole SOFC. In addition, the cell performance increases about $50.54 \%$ as the working temperature is increased from $873 \mathrm{~K}$ to $1273 \mathrm{~K}$. A higher working temperature enhances the fluid velocity and convection and consequently promotes the chemical reaction and obtains a better cell performance.
\end{abstract}

\section{Introduction}

Solid oxide fuel cells (SOFCs) provide many advantages over traditional energy conversion systems including high efficiency, reliability, modularity, fuel adaptability, and very low levels of SOx and NOx emissions. Quiet and vibration-free operation of solid oxide fuel cells also eliminates noise usually associated with conventional power generation systems. Furthermore, because of their high operation temperature (800$1000^{\circ} \mathrm{C}$ ), some hydrocarbon fuels such as natural gas can be reformed within the cell stack eliminating the need for an expensive, external reformer [1].

Button cells are the simplest SOFC setup that could be utilized to study the anodic and cathodic processes under various operating temperatures and inlet fuel conditions. The primary purpose of button cell testing is to provide a method of evaluating the effects of changes in cell component and fabrication processes on cell performance. A considerable number of experimental investigations have been performed on button cells to the present [2-6]. Shao and Haile [2] used BSCF as a new cathode material for reduced-temperature SOFC operation. The high power output of BSCF cathodes results from the high rate of oxygen diffusion through the material. Zhao and Virkar [3] investigated experimentally the effect of various parameters of YSZ electrolyte thickness, cathode interlayer thickness, anode support thickness, and anode support porosity on cell performance. Tao and Irvine [4] reported a nickelfree SOFC anode, $\mathrm{La}_{0.75} \mathrm{Sr}_{0.25} \mathrm{Cr}_{0.5} \mathrm{Mn}_{0.5} \mathrm{O}_{3}$, with comparable electrochemical performance to Ni/YSZ cermets, and then obtained a very good performance for methane oxidation without using excess steam. Lin et al. [5] described experimentally the operation of Ni-YSZ anode-supported SOFCs on methane fuel. Liu and Barnett [6] successfully operated solid oxide fuel cells (SOFCs) with thin yttria-stabilized zirconia (YSZ) electrolytes on porous Ni-YSZ anodes with humidified methane and natural gas.

There are recently many papers on the modeling and simulation of SOFC button cell. Numerical modeling is employed to predict cell behavior under a variety of conditions and to 


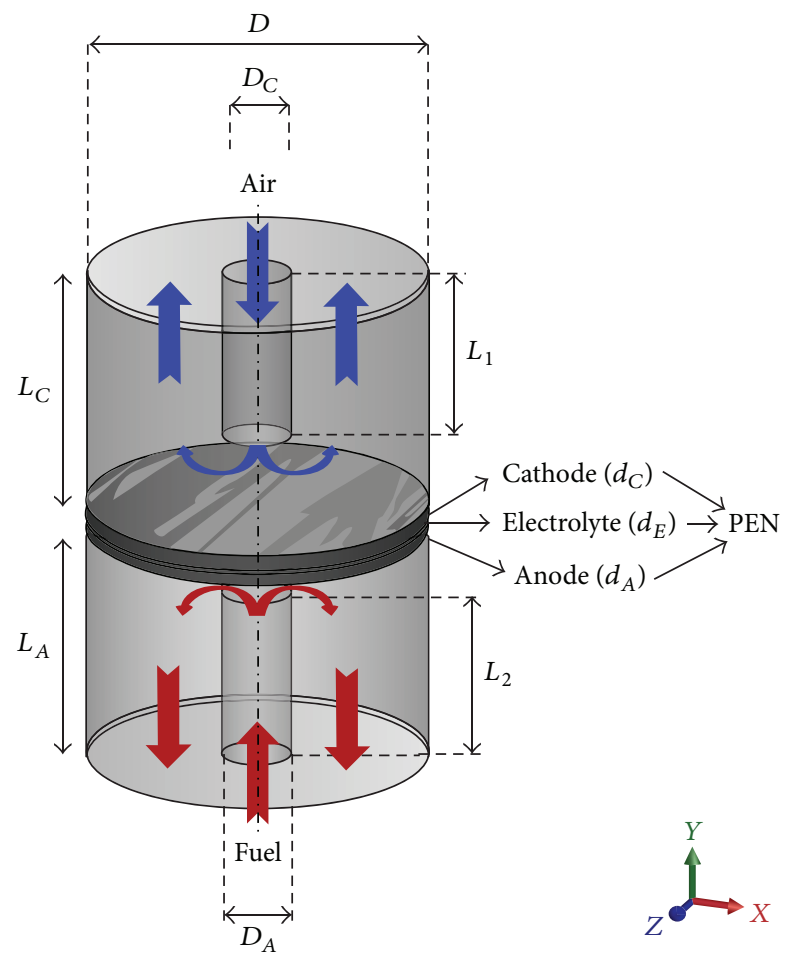

FIGURE 1: The button cell configuration used for simulation.

investigate the effect and the relative importance of various processing and operating parameters [7-12]. Chan et al. [7] numerically evaluated the performance of SOFC button cells under various designs and operating conditions using a new model. Zhu and Kee [8] developed a numerical model to investigate the influences of different polarization resistances on the performance of SOFC button cell. Suwanwarangkul et al. [9] adopted two numerical isothermal models to observe the performance of a SOFC button cell operated with a syngas fuel. Janardhanan and Deutschmann [10] utilized a numerical model to analyze the chemical processes within the anode, electrochemical processes, and losses of SOFC button cells operating with $\mathrm{CH} 4$ rich fuel under internal reforming conditions. Autissier et al. [11] used the commercial software, FLUENT, to compute the reaction rate, current density, reactant transport, and temperature in the anode-supported cell. Liu et al. [12] used a commercial CFD code, Star-CD, to investigate the performance of an anodesupported SOFC. Their results showed that the power density increases when the fuel utilization reduces as the fuel flow rate increases. However, few studies investigated the influences of various geometric designs of cell components on the cell performance. Therefore, the objective of the present paper is to numerically evaluate the enhancement of various geometric designs on cell performance and heat/mass transport characteristics by changing the anode thickness of SOFC button cell with different operating temperatures using $3 \mathrm{D}$ SIMPLE-C numerical method coupled with preconditioned conjugate gradient methods.

\section{Numerical Modeling}

This paper considers the physical problem of a threedimensional anode-supported SOFC button cell model (Figure 1) to investigate the influences of various anode thicknesses and operating temperatures on the heat/mass transport characteristics and cell performance. To observe the influences of various anode thicknesses and operating temperatures, all modified flow fields have the same length and diameter of channel. The present study employed the 3D Cartesian coordinate system for the physical model and utilized the assumptions in this model as follows.

(1) The fluid flow is laminar, incompressible, and unsteady; its physical properties are assumed constant.

(2) The gas behaves as ideal gas.

(3) The porous medium is isotropic and homogeneous with uniform morphological properties.

The 3D governing equations for the fluid in an anodesupported SOFC button cell are expressed as follows. Equations (1)-(4) are, respectively, continuity, momentum, energy, and species equations:

$$
\begin{gathered}
\frac{\partial \rho}{\partial t}+\frac{\partial \rho u_{j}}{\partial x_{j}}=S_{m} \\
\frac{\partial \rho u_{i}}{\partial t}+\frac{\partial}{\partial x_{j}}\left(\rho u_{j} u_{i}-\tau_{i j}\right)=-\frac{\partial P}{\partial x_{i}}+S_{i}
\end{gathered}
$$




$$
\begin{gathered}
\frac{\partial \rho h}{\partial t}+\frac{\partial}{\partial x_{j}}\left(\rho h u_{j}+F_{h, j}\right)=\frac{\partial P}{\partial t}+u_{j} \frac{\partial P}{\partial x_{j}}+\tau_{i j} \frac{\partial u_{i}}{\partial x_{j}}+S_{h} \\
\frac{\partial \rho Y_{m}}{\partial t}+\frac{\partial}{\partial x_{j}}\left(\rho u_{j} Y_{m}+F_{m, j}\right)=R_{m}
\end{gathered}
$$

where $S_{m}$ and $S_{i}$ are the source terms induced by the body and external forces. $\tau_{i j}$ represents the stress tensor, $F_{m}$ the diffusion flux component, and $R_{m}$ the rate of mass production or consumption in the chemical reaction. In addition, $\rho$ is the density of mixture as follows:

$$
\rho=\frac{P}{\mathrm{RT}}\left(\sum_{m} \frac{Y_{m}}{M_{m}}\right)
$$

where $Y_{m}$ is the mass fraction and $M_{m}$ is the molecular weight. The specific enthalpy of fluid $(h)$ is calculated from

$$
h=c_{P} T-c_{P}^{0} T^{0}+\sum Y_{m} H_{m}
$$

where $H_{m}$ is the formation heat of constituent $m, c_{p}$ the mean constant-pressure specific heat for the temperature $T$, and $c_{P}^{0}$ the reference specific heat for the reference temperature $T^{0}$.

In the electrochemical model, the following electrochemical reactions (7)-(8) are considered in cathode and anode sides. The two limiting current densities for the chemical reactors can be determined as in (9)-(10) as follows:

$$
\begin{aligned}
& \text { cathode side: } \mathrm{O}_{2}+4 \mathrm{e}^{-} \longrightarrow 2 \mathrm{O}^{2-} \quad\left(n_{e}=4\right), \\
& \text { anode side: } \mathrm{H}_{2}+\mathrm{O}^{2-} \longrightarrow \mathrm{H}_{2} \mathrm{O}+2 \mathrm{e}^{-} \quad\left(n_{e}=2\right), \\
& \text { cathode side: } i_{\mathrm{C}}=\frac{4 F D_{\text {eff }}(T) P_{\mathrm{O}_{2}}}{\mathrm{RT} d_{\mathrm{C}}} \ln \left(\frac{P_{\text {system }}}{P_{\text {system }}-P_{\mathrm{O}_{2}}}\right), \\
& \text { anode side: } i_{\mathrm{A}}=\frac{2 F D_{\text {eff }}(T) P_{\mathrm{H}_{2}}}{\mathrm{RT} d_{\mathrm{A}}},
\end{aligned}
$$

where $D_{\text {eff }}(T)$ is the effective diffusion coefficient, $P_{\mathrm{H}_{2}}$ and $P_{\mathrm{O}_{2}}$ are the partial pressure of hydrogen and oxygen, $F$ is the Faraday constant, and $d_{\mathrm{A}}$ and $d_{\mathrm{C}}$ are, respectively, the thickness of anode and cathode. Electrical performance is obtained from the resulting fuel and air compositions.

The cell voltage is calculated from $V(i)=V_{\text {Nernst }}-V_{\text {Ohmic }}-$ $V_{\text {Butler-Volmer }}+V_{\text {cathode }}+V_{\text {anode }}$, where $V_{\text {Nernst }}$ is the open circuit potential, $V_{\text {Ohmic }}$ the Ohmic potential drop, $V_{\text {Butler-Volmer }}$ the Butler-Volmer polarization, $V_{\text {cathode }}$ the cathode polarization, and $V_{\text {anode }}$ the anode polarization. All items are calculated from

$$
\begin{gathered}
V_{\text {Nernst }}=\frac{\mathrm{RT}}{4 F} \ln \left(\frac{P_{\mathrm{O}_{2}, \text { cathode }}}{P_{\mathrm{O}_{2}, \text { anode }}}\right), \\
V_{\text {Ohmic }}=i R_{i},
\end{gathered}
$$

TABLE 1: Geometric and physical parameters used in this study.

\begin{tabular}{lc}
\hline Quantity & Value \\
\hline Cell diameter, $D(\mathrm{~mm})$ & 20 \\
PEN thickness $(\mathrm{mm})$ & 0.555 \\
Anode thickness, $d_{A}(\mathrm{~mm})$ & $0.1,0.5,1.0$ \\
Electrolyte thickness, $d_{E}(\mathrm{~mm})$ & 0.025 \\
Cathode thickness, $d_{C}(\mathrm{~mm})$ & 0.03 \\
Length of flow channel $(\mathrm{mm})$ & 10 \\
Diameter of flow channel $(\mathrm{mm})$ & 7 \\
Interconnect thickness $(\mathrm{mm})$ & 15 \\
Porosity & 0.3 \\
Operating temperature $(\mathrm{K})$ & 1073,1273 \\
Operating pressure $($ atm $)$ & 1 \\
Relative humidity & $100 \%$ \\
Fuel inlet temperature $\left({ }^{\circ} \mathrm{C}\right)$ & 800 \\
Preexponential factor, $A_{i}$ & 128 \\
Universal gas constant, $R\left(\mathrm{~J} \mathrm{~mol}{ }^{-1} \mathrm{~K}^{-1}\right)$ & 8.314 \\
Activation energy, $E_{\text {act }}\left(\mathrm{J} \mathrm{mol}{ }^{-1}\right)$ & 550 \\
Fuel input mass flow rate $(\mathrm{kg} / \mathrm{sec})$ & $2.4 \times 10^{-7}$ \\
Air input mass flow rate $(\mathrm{kg} / \mathrm{sec})$ & $1.3 \times 10^{-5}$ \\
\hline
\end{tabular}

$$
\begin{gathered}
V_{\text {Butler-Volmer }}=\frac{\mathrm{RT}}{\alpha F} \sinh ^{-1}\left(\frac{i}{2 i_{0}}\right), \\
V_{\text {cathode }}=\frac{\mathrm{RT}}{4 F} \ln \left(1-\frac{i}{i_{\mathrm{c}}}\right), \\
V_{\text {anode }}=\frac{\mathrm{RT}}{2 F} \ln \left(1-\frac{i}{i_{\mathrm{a}}}\right), \\
i_{0}=A_{i} \cdot \exp \frac{-E_{\mathrm{act}}}{\mathrm{RT}},
\end{gathered}
$$

where $i_{0}$ is the exchange current density, $A_{i}$ the prefactor, and $E_{\text {act }}$ the activation energy.

The boundary conditions required for the computational domain are shown in Figure 1. The boundary conditions of inlet are listed in Table 1. The outlet ambient static pressures at anode and cathode are specified and obtained by extrapolating from the interior flow. No-slip condition is set for velocity and the coupled boundary conditions are applied to temperature, and the flux of species equals zero on the interface between fluid domain and solid domain. The temperature on the wall surface of the SOFC is specified as cell operation ambient temperature in the present study.

The SIMPLE-C algorithm [13] with the control-volume approach is adopted to derive the discretized forms of all transport equations arranged into transient, diffusion, convection, and source terms. Adopting extended linear upwind differencing (ELUD) [14] to discretize the convective terms and a second-order backward Euler (SBE) [15] to discretize the transient term derives the fully discretized 


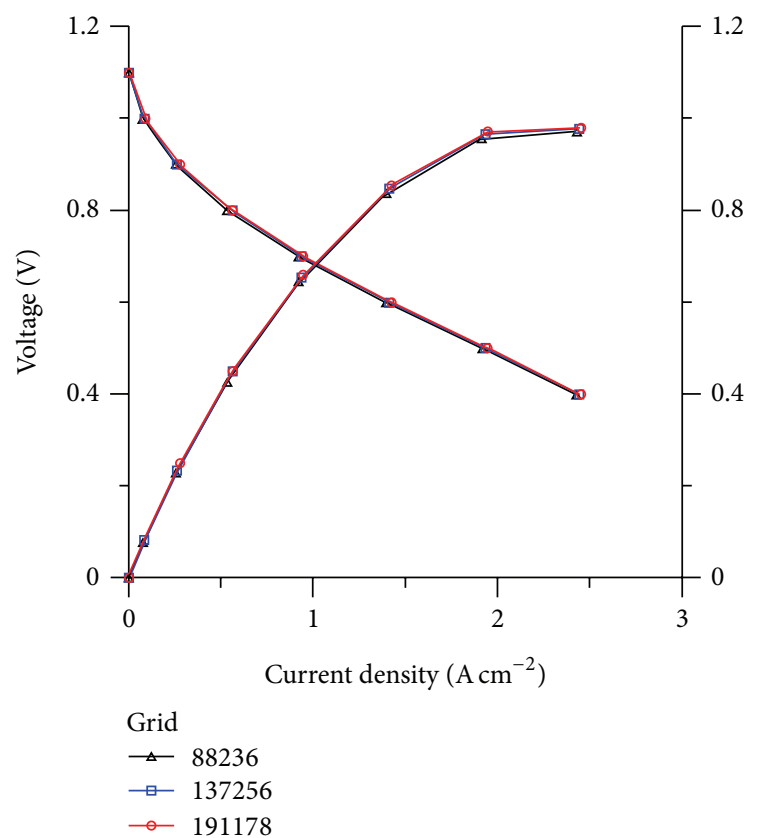

(a)

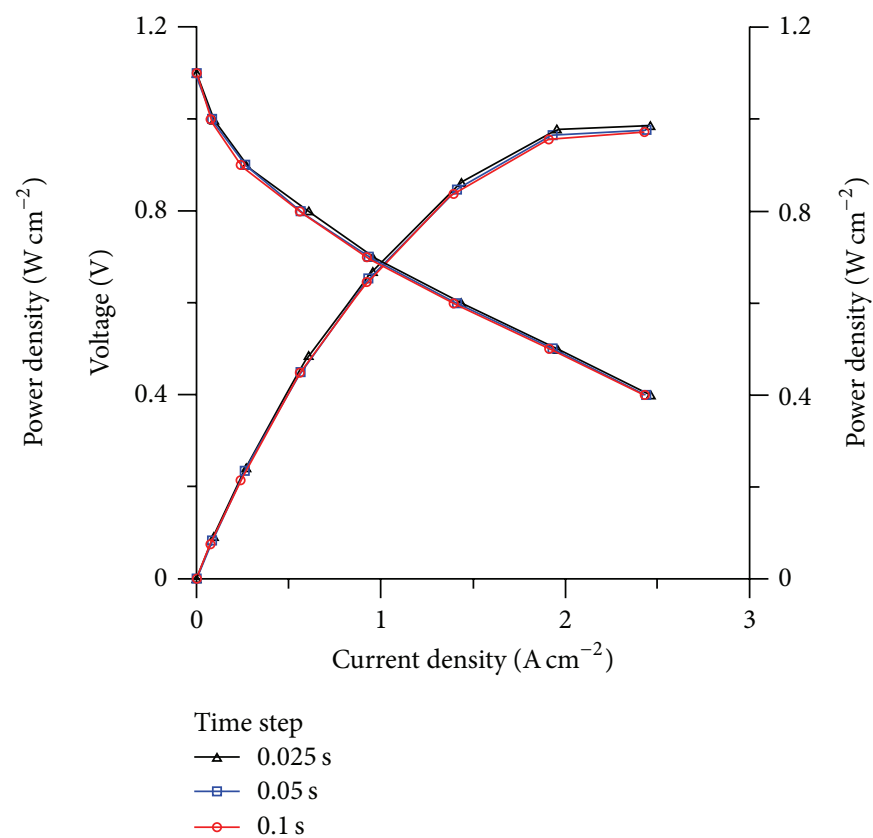

(b)

FIGURE 2: Comparison of voltage and power density distributions for various (a) grid systems; (b) time steps with anode thickness equal to $0.5 \mathrm{~mm}$ at $1073 \mathrm{~K}$.

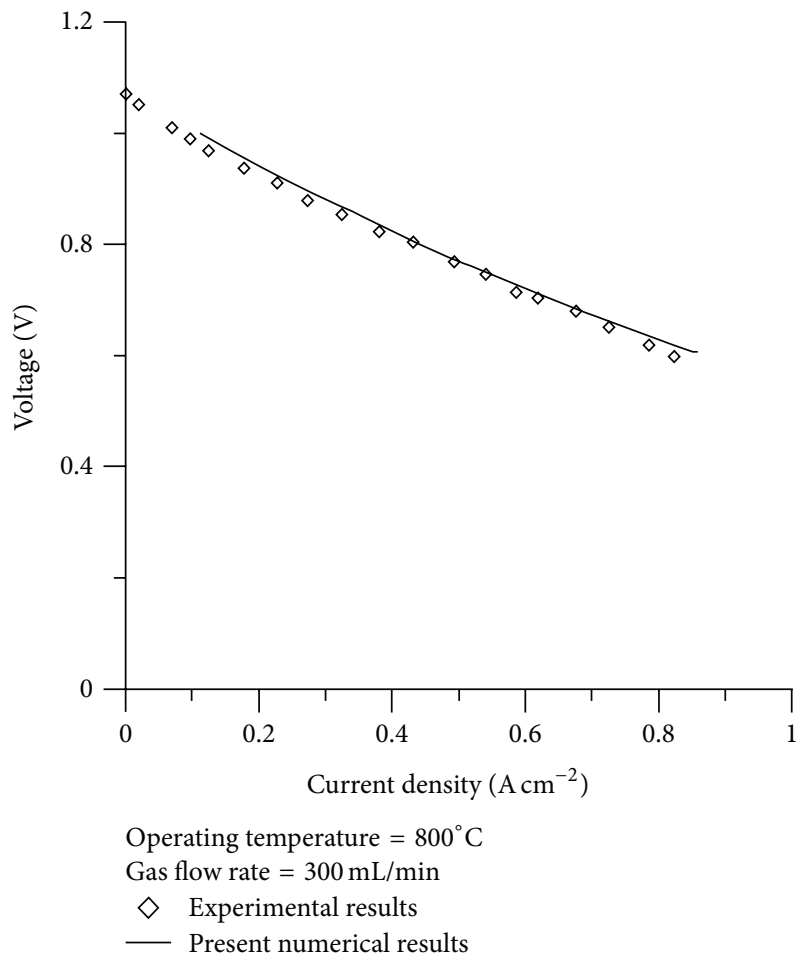

FIGURE 3: Comparison of the results between the present prediction and Liu's experimental results [12].

equations by means of control-volume method. These discretized equations are easily implemented into the SIMPLE-C algorithm. The iterative solution methods on the basis of the preconditioned conjugate gradient method are incorporated into this code $[16,17]$.

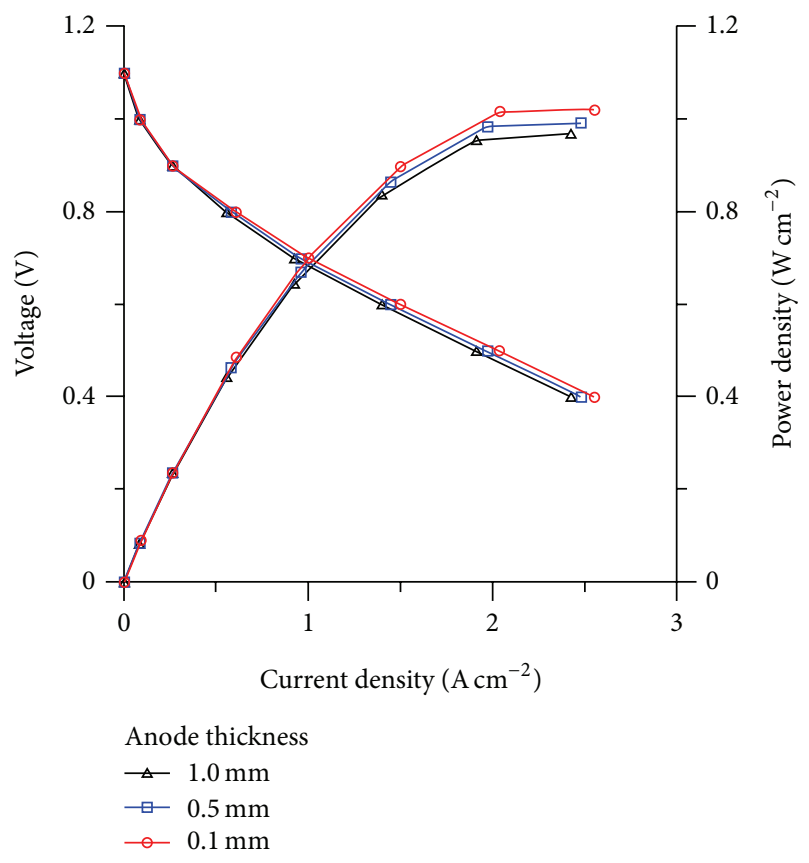

FIGURE 4: The polarization curves of the fuel cell performance for different anode thickness.

\section{Results and Discussion}

In this study, the simulation was carried out for different anode thicknesses and operating temperatures with constant inlet fuel and air flow conditions as specified in Table 1. In order to examine the effect of grid number on the numerical results, the grid independence was observed in a series of test 

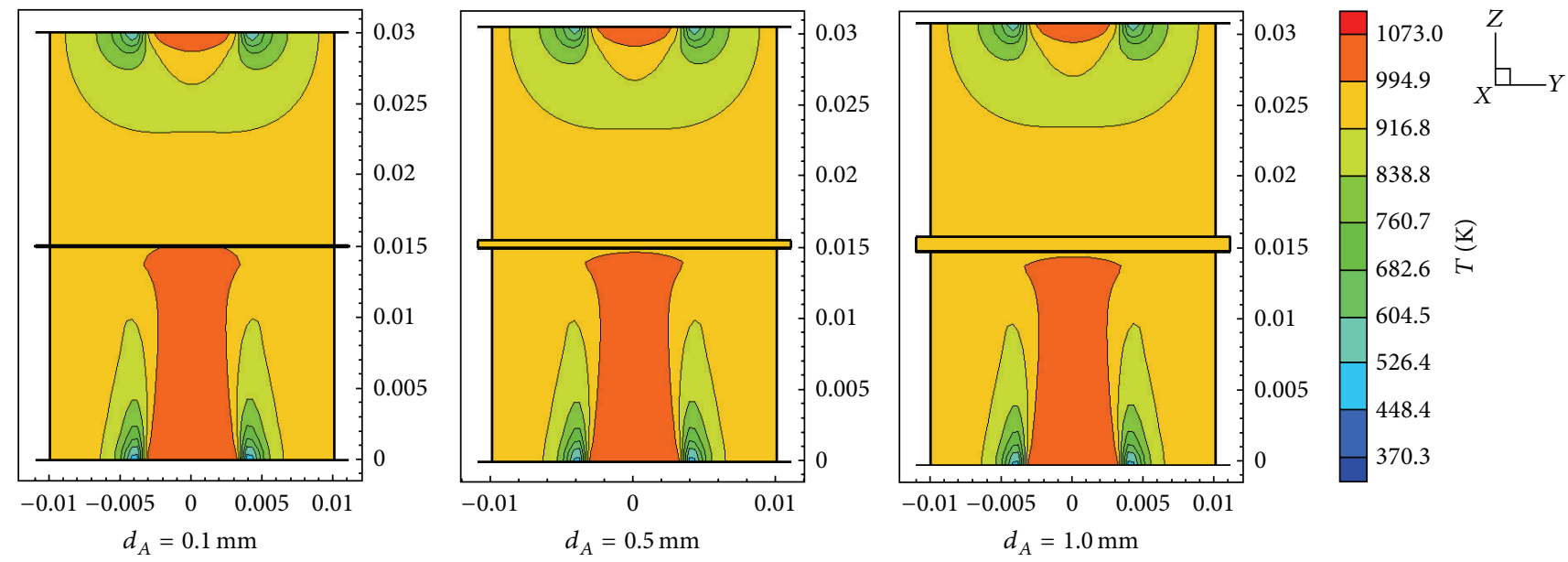

(a)
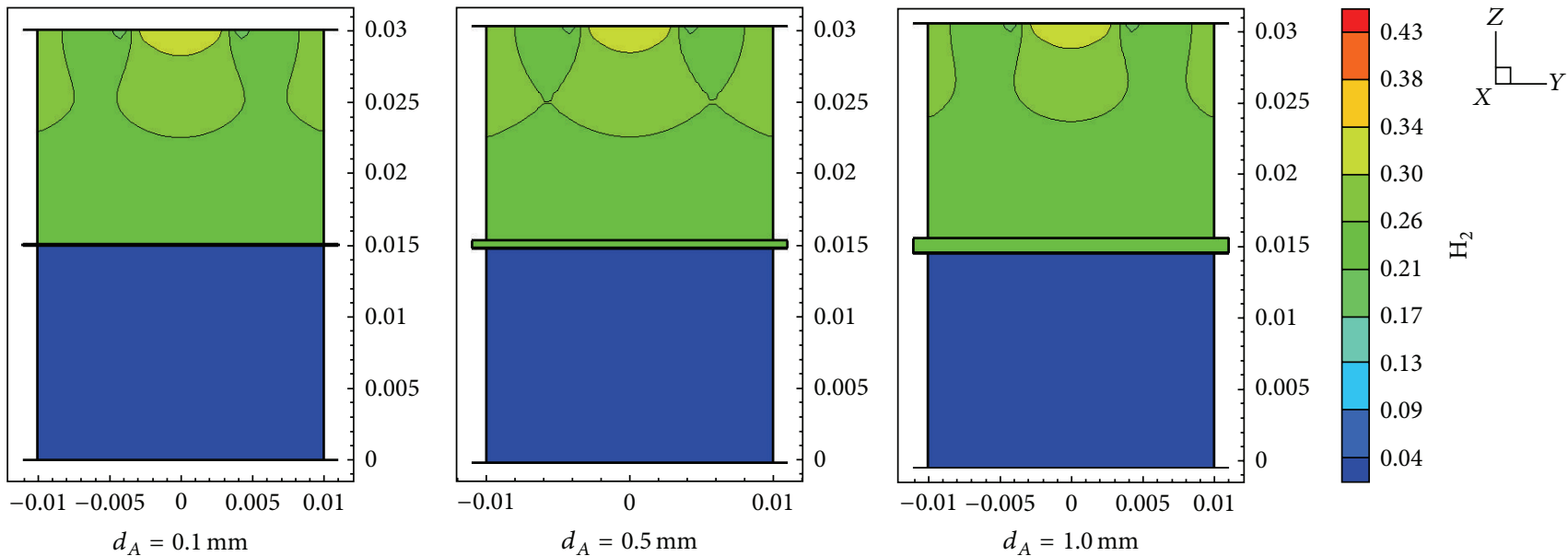

(b)
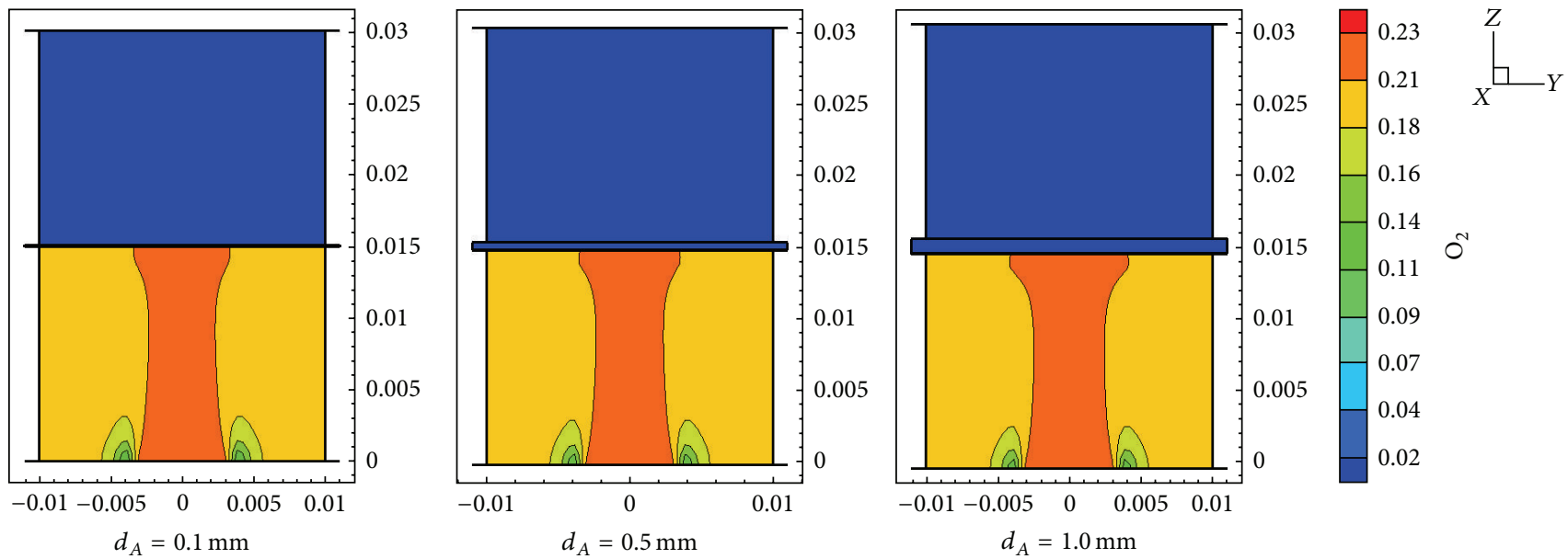

(c)

FIgURE 5: The distributions of (a) temperature; (b) hydrogen; (c) oxygen for different anode thicknesses at $0.6 \mathrm{~V}$ and $1073 \mathrm{~K}$. 
runs. The test results for various grid systems (88236, 137256, and 191178 nodes) are indicated in Figure 2(a). The difference of cell voltage and power density distributions between the second and the third grid system was less than 0.05 percent in test runs, so the third grid system (137256 nodes) was selected in all cases for saving the computer computational time and having the numerical results closer to the true results. The time step size is adjusted in this numerical code from stability and accuracy criteria with the initial time step size given as an input. The three time steps $0.025,0.05$, and $0.1 \mathrm{sec}$ were chosen to test the time step size sensitivity. As the results were compared in Figure 2(b), the time increment could be set as $0.05 \mathrm{sec}$ for the calculations of unsteady laminar flow in a SOFC. To demonstrate the capability of the program in this study in handling SOFC cell performance, the authors solved the cell performance of a SOFC mentioned by Liu et al. [12] by applying this present numerical process. In Figure 3, the numerical results of the present study are compared with Liu's experimental data, and the overall relative difference between the curves is less than $3.8 \%$ and good agreement is observed.

This paper will use the cell polarization curves below to demonstrate how various anode thicknesses and operating temperatures influence SOFC button cell performance. Figure 4 shows the variation of the cell output voltage and the power density with the thickness of the anode layer in different current densities. As shown in the figure, the effect of the anode thickness is minimal in low current densities. In the high current densities, this effect becomes more important so that the maximum power density decreased from $1.021 \mathrm{~W} \mathrm{~cm}^{-2}$ to $0.969 \mathrm{~W} \mathrm{~cm}^{-2}$ when the anode thickness is increased from $0.1 \mathrm{~mm}$ to $1.0 \mathrm{~mm}$. The cell performance reduces about $5.05 \%$ as the anode thickness is changed from $0.1 \mathrm{~mm}$ to $1.0 \mathrm{~mm}$. This trend is similar to references' results $[3,18]$. When the anode thickness is increased, the distance between the anode inlet and the electrolyte becomes longer. This caused the stronger drag generated by the thicker anode side, which decelerates fluid flow. The above phenomenon can cause the fuel to move hardly toward the electrolyte and accordingly reduces the cell performance. Besides, the larger anode thickness obtains the worse cell performance due to increase of the Ohmic loss for the anode-supported solid oxide fuel cells. Figure 5 presents the influences of various anode thicknesses on the heat/mass transport phenomenon in the SOFC. From the results, the influence of various anode thicknesses on the distributions of temperature, hydrogen, and oxygen is slight. This is due to the fact that the anode thickness is small as compared with the size of SOFC. The above phenomena illustrated in Figure 5 interpret the cell polarization curves of SOFC as presented in Figure 4.

Figure 6 shows the variation of the cell output voltage and the power density with various operating temperatures in different current densities. As shown in the figure, the effect of the operating temperature on the cell output voltage and the power density is obvious. The maximum power density increases from $0.792 \mathrm{~W} \mathrm{~cm}^{-2}$ to $1.192 \mathrm{~W} \mathrm{~cm}^{-2}$ when the operating temperature is increased from $873 \mathrm{~K}$ to $1273 \mathrm{~K}$. The cell performance increases about $50.54 \%$ as the operating temperature is changed from $873 \mathrm{~K}$ to $1273 \mathrm{~K}$.

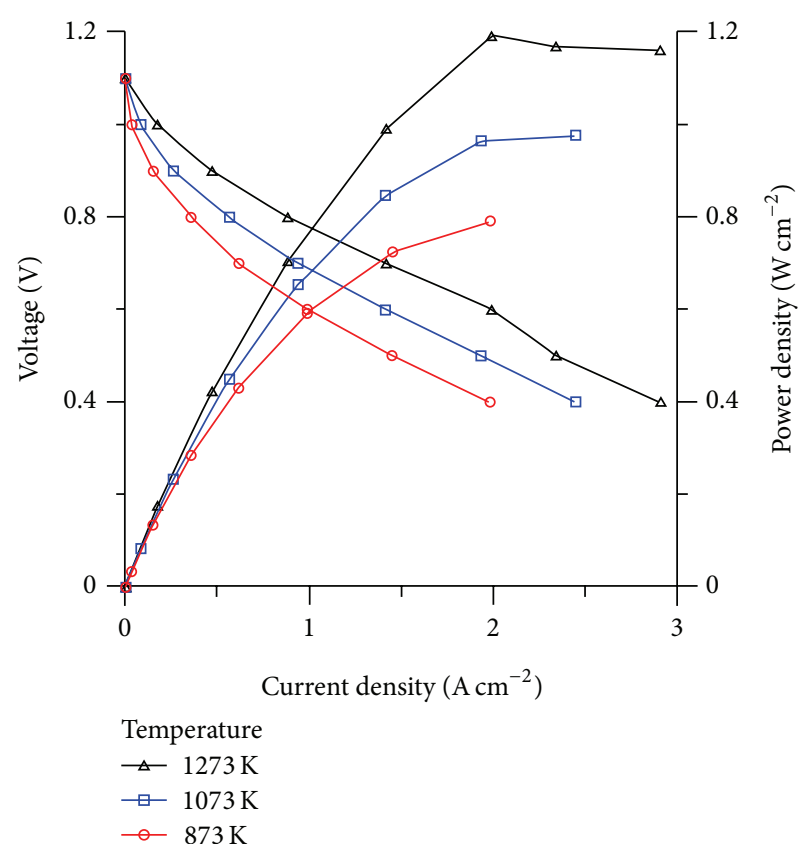

FIgURE 6: The polarization curves of the fuel cell performance for different operating temperatures.

This trend is similar to references' results [3]. This is due to the low ionic conductivity of electrolyte material and lower rate of electrochemical reactions at lower temperatures. Consequently, the lower temperature leads to the lower cell performance. This paper plots Figure 7 to comprehend the effect of various operating temperatures on the heat/mass transport phenomenon in the SOFC. In Figure 7(a), the velocity of fluid increases with an increase in the operating temperature, because a higher temperature leads to a stronger convection, which supplies more fuel to enhance the chemical reaction and promotes the removal of liquid water from the SOFC, and then obtains a better cell performance. In Figures $7(\mathrm{~b})$ and $7(\mathrm{c})$, the distributions of hydrogen and oxygen increase as the operating temperature increases since a higher temperature causes a stronger convection to enhance the reactant transport. The above phenomena illustrated in Figure 7 explain the cell polarization curves of SOFC as presented in Figure 6.

\section{Conclusion}

A three-dimensional numerical model is developed to investigate the effects of anode thickness and operating temperature on the performance of an anode-supported SOFC button cell. The conclusions from the results discussed are drawn as follows.

(1) The results of SOFC cell performance computed in the present study are in good agreement with available measurements of Liu.

(2) The maximum power density decreased from $1.021 \mathrm{~W} \mathrm{~cm}^{-2}$ to $0.969 \mathrm{~W} \mathrm{~cm}^{-2}$ as the anode thickness 

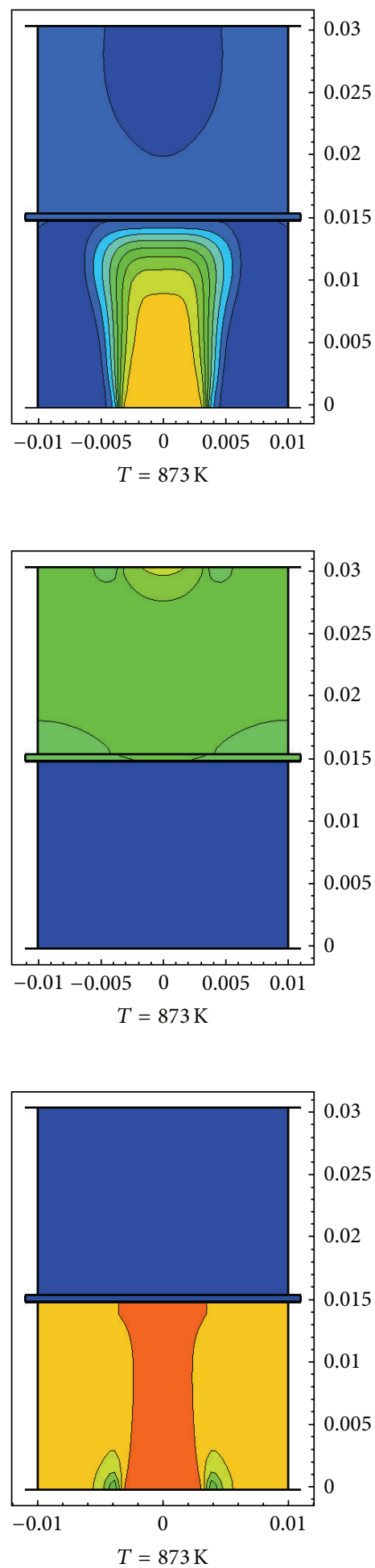

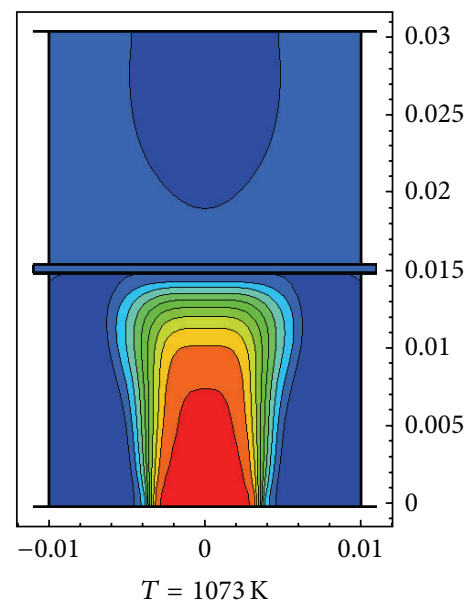

(a)

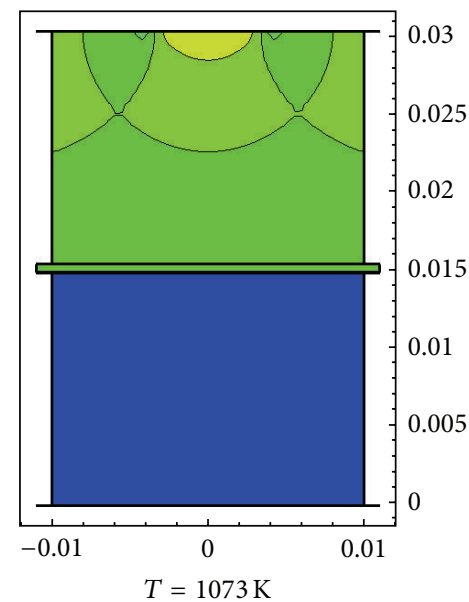

(b)
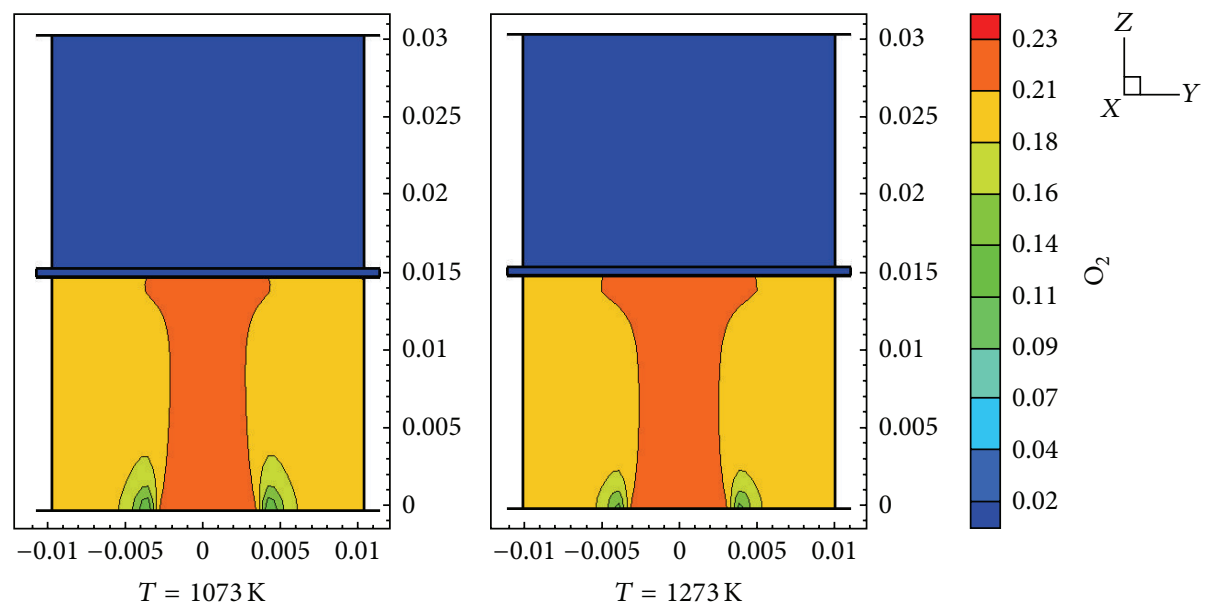

(c)

FIGURE 7: The distributions of (a) velocity; (b) hydrogen; (c) oxygen for different operating temperatures with anode thickness equal to $0.5 \mathrm{~mm}$ at $0.6 \mathrm{~V}$. 
is increased from $0.1 \mathrm{~mm}$ to $1.0 \mathrm{~mm}$, and thus the cell performance reduces about $5.05 \%$.

(3) The influence of various anode thicknesses on the heat/mass transport is slight, because the anode thickness is small as compared with the size of SOFC.

(4) The maximum power density increases from $0.792 \mathrm{~W} \mathrm{~cm}^{-2}$ to $1.192 \mathrm{~W} \mathrm{~cm}^{-2}$ as the operating temperature is increased from $873 \mathrm{~K}$ to $1273 \mathrm{~K}$, and thus the cell performance increases about $50.54 \%$.

(5) A higher temperature leads to a stronger convection, which supplies more fuel to enhance the chemical reaction and promotes the removal of liquid water from the SOFC, and then obtains a better cell performance.

\section{Conflict of Interests}

The authors declare that there is no conflict of interests regarding the publication of this paper.

\section{Acknowledgment}

The authors are indebted to the Ministry of Science and Technology of the Republic of China for its financial support with the projects of NSC 101-2221-E-168-017.

\section{References}

[1] S. C. Singhal, "Solid oxide fuel cells for stationary, mobile, and military applications," Solid State Ionics, vol. 152-153, pp. 405410, 2002.

[2] Z. Shao and S. M. Haile, "A high-performance cathode for the next generation of solid-oxide fuel cells," Nature, vol. 431, pp. 170-173, 2004.

[3] F. Zhao and A. V. Virkar, "Dependence of polarization in anodesupported solid oxide fuel cells on various cell parameters," Journal of Power Sources, vol. 141, no. 1, pp. 79-95, 2005.

[4] S. Tao and J. T. S. Irvine, "A redox-stable efficient anode for solid-oxide fuel cells," Nature Materials, vol. 2, no. 5, pp. 320323,2003

[5] Y. Lin, Z. Zhan, J. Liu, and S. A. Barnett, "Direct operation of solid oxide fuel cells with methane fuel," Solid State Ionics, vol. 176, no. 23-24, pp. 1827-1835, 2005.

[6] J. Liu and S. A. Barnett, "Operation of anode-supported solid oxide fuel cells on methane and natural gas," Solid State Ionics, vol. 158, no. 1-2, pp. 11-16, 2003.

[7] S. H. Chan, K. A. Khor, and Z. T. Xia, "Complete polarization model of a solid oxide fuel cell and its sensitivity to the change of cell component thickness," Journal of Power Sources, vol. 93, no. 1-2, pp. 130-140, 2001.

[8] H. Zhu and R. J. Kee, "A general mathematical model for analyzing the performance of fuel-cell membrane-electrode assemblies," Journal of Power Sources, vol. 117, no. 1-2, pp. 61-74, 2003.

[9] R. Suwanwarangkul, E. Croiset, E. Entchev et al., "Experimental and modeling study of solid oxide fuel cell operating with syngas fuel," Journal of Power Sources, vol. 161, pp. 308-322, 2006.
[10] V. M. Janardhanan and O. Deutschmann, "CFD analysis of a solid oxide fuel cell with internal reforming: coupled interactions of transport, heterogeneous catalysis and electrochemical processes," Journal of Power Sources, vol. 162, no. 2, pp. 11921202,2006

[11] N. Autissier, D. Larrain, J. van Herle, and D. Favrat, "CFD simulation tool for solid oxide fuel cells," Journal of Power Sources, vol. 131, no. 1-2, pp. 313-319, 2004.

[12] H.-C. Liu, C.-H. Lee, Y.-H. Shiu, R.-Y. Lee, and W.-M. Yan, "Performance simulation for an anode-supported SOFC using Star-CD code," Journal of Power Sources, vol. 167, no. 2, pp. 406412,2007

[13] J. P. van Doormaal and G. D. Raithby, "Enhancements of the simple method for predicting incompressible fluid flows," Numerical Heat Transfer, vol. 7, no. 2, pp. 147-163, 1984.

[14] Y. Y. Tsui, "A study of upstream-weighted high-order differencing for approximation to flow convection," International Journal for Numerical Methods in Fluids, vol. 13, pp. 167-199, 1991.

[15] G. B. Deng, J. Piquet, P. Queutey, and M. Visonneau, "A new fully coupled solution of the Navier-Stokes equations," International Journal for Numerical Methods in Fluids, vol. 19, no. 7, pp. 605-639, 1994.

[16] D. S. Kershaw, "The incomplete Cholesky-conjugate gradient method for the iterative solution of systems of linear equations," Journal of Computational Physics, vol. 26, no. 1, pp. 43-65, 1978.

[17] H. A. van der Vorst, "Bi-CGSTAB: a fast and smoothly converging variant of Bi-CG for the solution of nonsymmetric linear systems," Society for Industrial and Applied Mathematics, vol. 13, no. 2, pp. 631-644, 1992.

[18] Y. M. Barzi, A. Raoufi, and H. Lari, "Performance analysis of a SOFC button cell using a CFD model," International Journal of Hydrogen Energy, vol. 35, no. 17, pp. 9468-9478, 2010. 

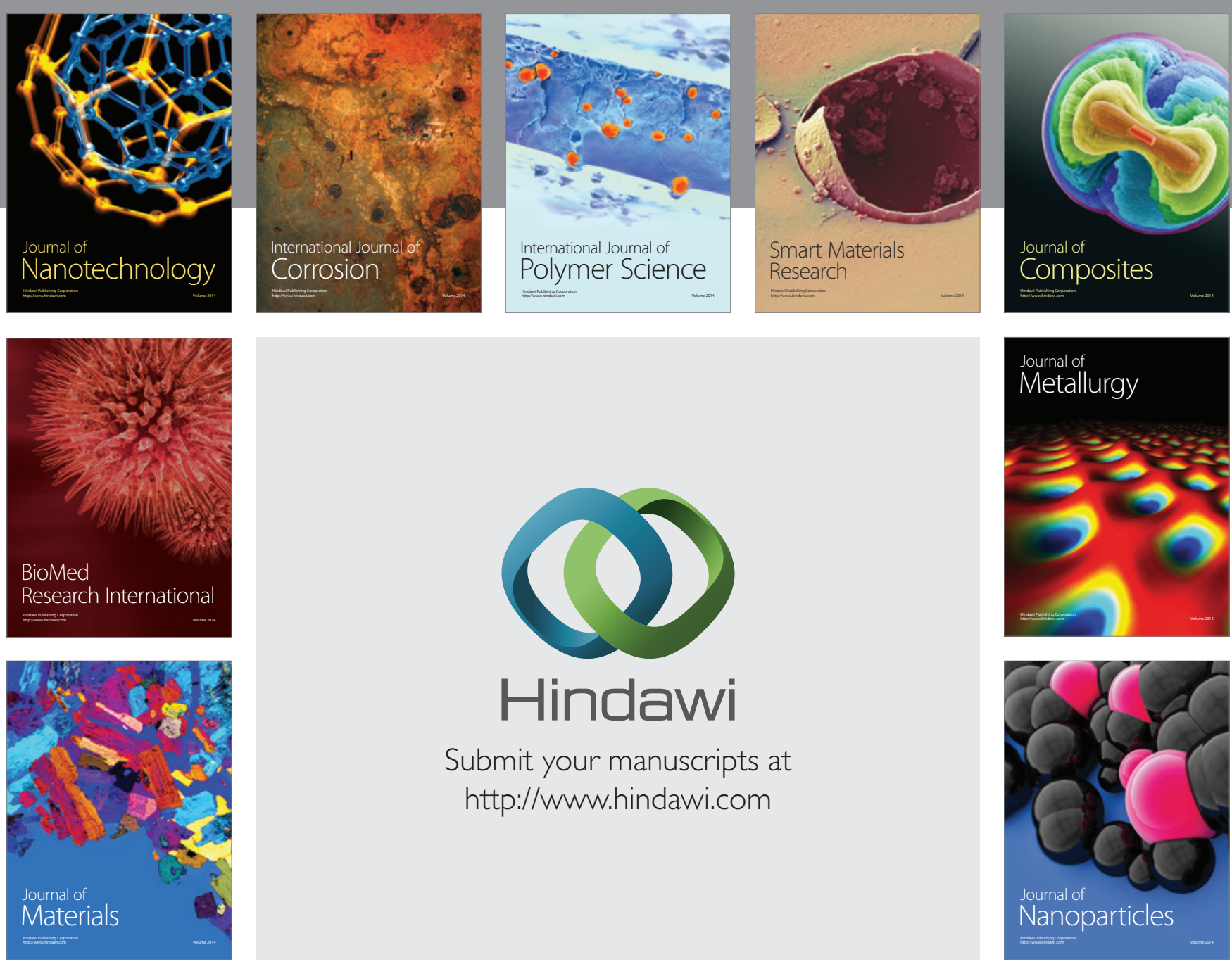

Submit your manuscripts at http://www.hindawi.com
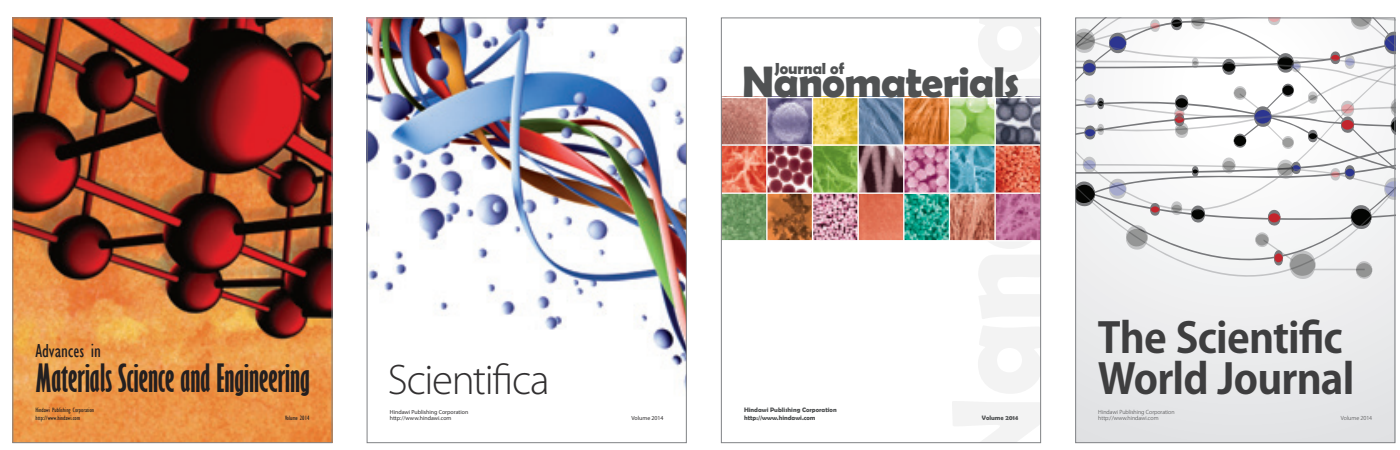

\section{The Scientific World Journal}
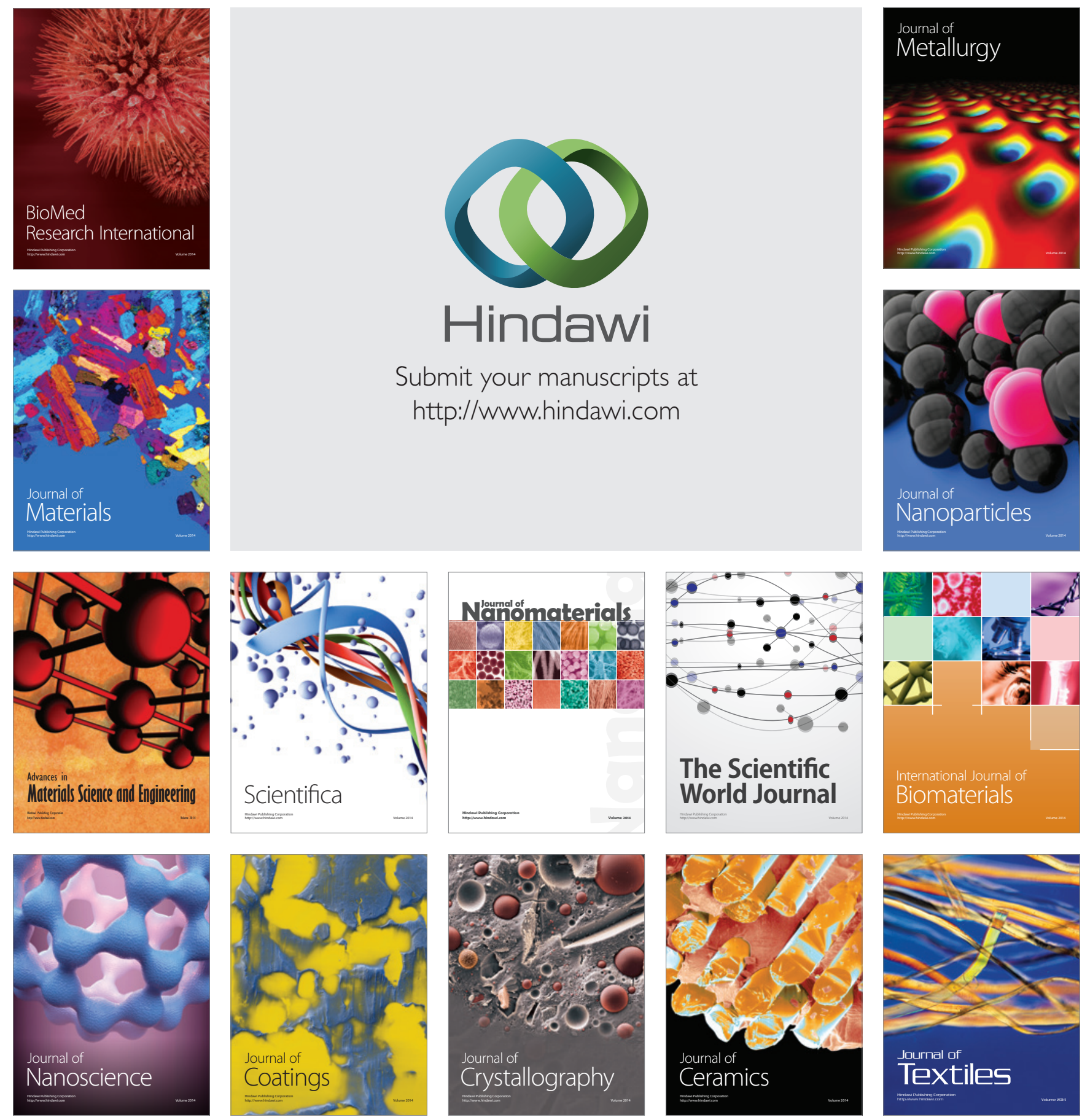